\title{
NOTES
}

\section{MALPRACTICE IMMUNITY: AN ILLEGITIMATE AND INEFFECTIVE RESPONSE TO THE INDIGENT-DEFENSE CRISIS}

\author{
HAROLD H. CHEN
}

"Not even a lawyer with an S on his chest could effectively handle this docket."1

\section{INTRODUCTION}

In 1963, the Supreme Court held in Gideon v. Wainwright that the Sixth Amendment requires states to appoint counsel for all indigent defendants charged with felonies in state court. ${ }^{2}$ Praising the Court's judicial activism, commentators and advocates for the poor hailed its ruling as long overdue. ${ }^{3}$ Three decades later, however, political and economic realities threaten the effective implementation of Gideon's guarantee. As the nation has intensified its zealous efforts to fight the "war" on crime and illegal drugs, the burdens on our criminal justice system have increased exponentially. ${ }^{4}$ Yet, while state legislatures have committed public resources to constructing more prisons and putting more pohice officers on the street, they largely have neglected to increase funding for indigent-defense programs. ${ }^{5}$ Thus, it is no surprise that a committee of the American Bar Association recently determined that most indigent-defense programs are in a state of crisis. ${ }^{6}$

1. State v. Peart, 621 So. $2 d 780,789$ (La. 1993) (quoting and affirming the trial judge's ruling that a public defender's excessive caseload and inadequate funding violated the constitutional guarantee of the right to counsel).

2. 372 U.S. 335 (1963).

3. See, e.g., ANTHONY LEwIS, GIDEON's TRUMPET (1964); Gerald F. Uelmen, 2001: A Train Ride: A Guided Tour of the Sixth Amendment Right to Counsel, LAw \& CONTEMP. PROBS., Winter 1995, at 1, 22-23.

4. Richard Klein \& Robert Spangenberg, The Indigent Defense Crisis, 1993 A.B.A. SEC. OF CRIM. JUST. $1,1$.

5. See infra notes $33-45$ and accompanying text.

6. Klein \& Spangenberg, supra note 4 , at 25 . 
It is against this troubled backdrop that several state courts have decided to depart from the traditional rule proscribing the grant of malpractice immunity to public defenders and court-appoimted counsel. ${ }^{7}$ Primarily within the last decade, courts im six states $^{8}$ have chosen to shield indigent-defense attorneys ${ }^{9}$ from malpractice suits brought by their indigent chents. This liability protection has come under the rubrics of qualified immunity and absolute immunity. Under qualified immunity, indigent-defense attorneys are considered state employees and thus are insulated from inalpractice hability for all discretionary acts and omissions committed in the course of their official duties. ${ }^{10}$ Absolute immunity, in contrast, uses public policy considerations as a basis for exeinpting indigent-defense attorneys from all tortious hability. ${ }^{11}$

Squarely disagreeing with this dramatic shift in the law, this Note argues that both forms of inalpractice immunity simply transfer the burdens of our troubled criminal justice system onto the backs of its weakest members-indigent criminal defendants. Although sympathetic of the hardships that indigent-defense attorneys face on a daily basis, this Note asserts that the doctrine of malpractice immunity is fundamentally mcompatible with our adversary system of criminal justice and our concept of professional accountability in the attorney-chent relationship. This Note further argues that the grant of malpractice immunity has unacceptable costs not only for indigent defendants but also for the legal profession and the general public. In consideration of these glaring flaws and the recent appearance of immunity in this area of the law, this Note concludes that inalpractice immunity is essentially a disingenuous judicial attempt to protect the pubhic treasury at the expense of the indigent criminal defendant.

7. This Note refers to the traditional view proscribing malpractice immunity as the "no-immunity rule." See infra Section II(A).

8. The state courts that have granted malpractice immunity are Delaware, Minnesota, Nevada, New Mexico, New York, and Vermont. This Note refers to these courts as the "immunity courts." With the exception of New York and New Mexico, courts of last resort of each state participated in the decision to grant immunity. See infra Section II(B).

9. Unless otherwise noted, the term "indigent-defense attorneys" imcludes both public defenders and court-appointed counsel. Of course, there are differences between these two types of attorneys, see text accompanying note 32, that may affect issues such as indemnification from suit.

10. Qualified immunity is discussed in full infra Section II(B)(1).

11. Absolute immunity is discussed in full infra Section II(B)(2). 
Part I of this Note traces the historical development of the right to counsel and describes the present crisis in indigent defense. Part II discusses the traditional no-immunity rule, examines the recent emergence of qualified and absolute immuurty, and analyzes the reasoning that animates both forms of immunity. Part III determines that malpractice immunity is inconsistent with our adversary systein of criminal justice and our standards of professional responsibility and accountability. In light of this critique, this Part concludes that immunity is nothing more than a judicial effort to msulate the state from having to pay damages to indigent chents who successfully sue their defense counsel for inalpractice. Finally, after considering several proposals for reform, Part IV argues that the no-immumity rule actually may provide a means of addressing the underlying cause of the indigent-defense crisis.

\section{The Right to Counsel: Past and PREsent}

The Sixth Amendinent commands that "[i]n all criminal prosecutions, the accused shall enjoy the right ... to have the Assistance of Counsel for his defence."12 Although inost Americans tacitly accept the right to counsel as an integral part of our criminal justice system, it has taken more than 170 years for these words to assunie their modern doctrinal meaning.

\section{A. The Evolution of the Sixth Amendment}

The right to counsel is rooted in the early history of the republic. In 1791, twelve of the thirteen origmal states had fully recognized the right to counsel in criminal prosecutions. ${ }^{13}$ This colomal practice of allowing criminal defendants to obtain counsel marked a radical departure froin traditional English criminal law. Under Enghish law, a defendant charged with a felony could retaim counsel ouly to discuss matters of pleading and specific questions of law at trial; an attorney could not argue questions of fact on a defendant's behalf. ${ }^{14}$ Somewhat paradoxically, a defendant charged with a misdemeanor, such as hibel or battery, was granted the full right to counsel. ${ }^{15}$

\footnotetext{
12. U.S. CONST. amend. VI.

13. Powell v. Alabama, 287 U.S. $45,64-65$ (1932).

14. 2 Wayne R. LaFave \& Jerold H. ISRael, Criminal Procedure $\S 11.1$, at 3

15. See Alexander Holtzoff, The Right of Counsel Under the Sixth Amendment, 20
} (1984). 
In stark contrast, most American colomes flatly rejected the idea of restricting the defense attorney's role in criminal prosecutions. In fact, the constitutions of Pennsylvania, South Carolina, and Delaware required that counsel be appointed for defendants accused of a capital crime; Connecticut's constitution even required that courts appoint counsel for all indigent defendants. ${ }^{16}$ And while several other colomes had not specifically enumerated the right to counsel im their constitutions at this point, there was "a greater awareness in American courts that [a defendant without an attorney] was at a serious disadvantage ... [an] awareness [that] became keener as the number of lawyers increased in colonial America." 17

Despite this appreciation of the need for legal representation in criminal proceedings, the Suprene Court's jurisprudence on the right to counsel lay dormant for more than 140 years. Beginning in 1932, the Court signaled its intention to give substance to the spare text of the Sixtl Amendment. In Powell v. Alabama, the Court acknowledged for the first time that the failure to appoint counsel for an indigent defendant could compromise his due process riglits. ${ }^{18}$ The Powell defendants were several black men charged with the alleged rape of two white girls. In three trials

N.Y.U. L. REV. 1, 4 (1944) (citing 1 JAMES F. ARCHBOLD, PRACTICE, PLEAdING AND EVIDENCE IN CRIMINAL CASES 584 (New York, Banks \& Brothers, 7th ed. 1860)); see also 2 LAFAVE \& ISRAEL, supra note 14, § 11.1, at 3. This common law rule remained a part of English criminal law until Parliament passed a statute in 1836 allowing counsel to present a full defense at felony trials. LEONARD W. LEVY, ORIGINS OF THE FIFTH AMENDMENT 322 (2d ed. 1986); see also Betts v. Brady, 316 U.S. 455, 466 (1942), overruled by Gideon v. Wainwright, 372 U.S. 335 (1963). The rationale behind this English rule was steeped in deference to the Crown and in the perception that felony defendants posed a greater danger to the ruling order. Office of Legal Policy, Department of Justice, The Sixth Amendment Right to Counsel Under the Massiah Line of Cases, $22 \mathrm{U}$. MiCH. J.L. REF. 661, 672 (1989). Agreeing with this logic, Lord Coke argued that the presence of counsel was unnecessary because the Crown would charge a person with a felony only when the evidence against him was "so clear and manifest ... [that] there [could] be no defence." David Fellman, The Constitutional Right to Counsel in Federal Courts, 30 NEB. L. REV. 559, 560 (1951) (citing SIR EDWARD COKE, INSTITUTES OF THE LAWS OF ENG. LAND, THIRD PART 29 (London, E. \& R. Brooke 1797)). Similarly, Sir James Stephen contended that the British government could not afford to be generous with suspected criminals because it lacked a standing army and an organized police force. Id. at 560-61 (citing 1 SiR JAMES STEPHEN, History OF THE CRIMINAL LAW OF ENGLAND 354-75 (1883)).

16. William M. Beaney, The Right to Counsel in American Courts 18-26 (1955).

17. Id. at 25 .

18. 287 U.S. $45,66-68$ (1932). 
completed in a single day, the jury found the defendants guilty and sentenced them to death; counsel was not provided at any of these trials. ${ }^{19}$ Recognizmg the injustice of these circumstances, the Court found that "the necessity of counsel was so vital and imperative that the failure of the trial court to make an effective appoimtment of counsel was likewise a demal of due process within the meaning of the Fourteenth Amendment." ${ }^{20}$ The Powell holding later was extended to require that indigent defendants have appoimted counsel in all federal criminal proceedings. ${ }^{21}$ Yet, because most criminal cases were and continue to be prosecuted at the state level, these rulings provided hittle assistance to inost indigent defendants. ${ }^{22}$

In Gideon v. Wainwright, the Warren Court ushered in a new and sweeping interpretation of the right to counsel. ${ }^{23}$ In Gideon, the Court held that the Sixth Amendment entitled an indigent defendant to appointed counsel im all felony cases-whether state or federal. ${ }^{24}$ Finding that state and federal governments "properly spend vast sums of money to establish machinery to try defendants accused of crime" and that attorneys are "essential to protect the public's interest in an orderly society," the Court concluded that there could be no justice if a defendant had to "face his accusers without a lawyer."25 As Justice Black stated, it would be inconsistent with our vision of justice to do otherwise: "The right of one charged with crime to counsel may not be deemed fundamental and essential to fair trials in some countries, but it is in ours."26 To the accused, a defense lawyer is a necessity, not a luxury. ${ }^{27}$

Subsequent rulings have contmued to broaden the scope of the Sixth Amendment and have entrenched the right to counsel as an essential part of our constitutional jurisprudence on criminal law. In Miranda $v$. Arizona, the Warren Court held that police must inform a suspect during pre-charge interrogations that an

19. Id. at $49-50$.

20. Id. at 71 .

21. Johnson v. Zerbst, 304 U.S. 458 (1938).

22. See Suzanne E. Mounts, Public Defender Programs, Professional Responsibility, and Competent Representation, 1982 WIS. L. REV. 473, 476.

23. 372 U.S. 335 (1963).

24. Id. at $342-45$.

25. Id. at 344 .

26. Id.

27. Id. 
attorney will be appointed for him if he cannot afford one. ${ }^{28}$ This responsibility to inform suspects about their Sixth Amendment rights later was apphed to all post-charge situations in which witnesses confront the defendant. ${ }^{29}$ Gideon's reach eventually was held to include defendants charged with misdeneanors when the Court ruled in Argersinger $v$. Hamlin that an attorney must be appointed in all cases in which incarceration could result. ${ }^{30}$

\section{B. The Current Crisis in Indigent Defense}

When the Court decided cases such as Gideon and Argersing$e r$, it did not prescribe a rigid system for providing legal services to indigent defendants. Rather, it gave the states substantial discretion to decide for themselves how to comply with Gideon's mandate that all defendants be provided with adequate legal representation. States have generally utilized a combination of three basic systems-public defender, assigned counsel, and a contract-based model-to fulfill their Sixth Amendment obligations. ${ }^{31}$ Most states, especially those with sizable urban areas, use a combination of public defenders and court-appointed counsel to provide indigent representation. ${ }^{32}$

28. 384 U.S. $436,444-45$ (1966).

29. Coleman v. Alabama, 399 U.S. 1, 9 (1970).

30. 407 U.S. 25, 40 (1972). Several other decisions have also interpreted the Sixth Amendment broadly. See In re Gault, 387 U.S. 1, 27-28 (1967) (extending due process protection to juveniles in delinquency proceedings leading to possible incarceration); Douglas v. California, 372 U.S. 353, 357-58 (1963) (holding that the Equal Protection Clause entitles the defendant to an attorney on first appeal).

31. Klein \& Spangeuberg, supra note 4 , at 3 (citing THE SPANGENBERG Group, INDIGENT DEFENSE SERVICES 5 (1992)).

32. A recent survey determined that public defender offices serve as the primary method of delivering criminal defense services to approximately $65 \%$ of the indigent population. Klein \& Spangenberg, supra note 4, at 7 (citing STANDING COMMITTEE ON LEGAL AID AND INDIGENT DEFENDANTS, AMERICAN BAR ASSOCIATION, AN INTRODUCTION TO DEFENSE SYSTEMS 15 (1986)). Most public defender offices are public or private nonprofit organizations staffed with full or part-time attorneys. Many states also use an assigned counsel system in which cases are distributed to private attorneys who are compensated on a case-by-case basis. A Department of Justice survey found that the greatest number of counties use some form of the assigned counsel system. The third form of coimsel provision is a contract-based system. Under this model, a group of attorneys agrees to provide representation to indigent clients in a jurisdiction for a specific period; in return, they receive compensation from the state or county. The Department of Justice survey foumd that 1,144 counties einploy a pnblic defender system, 1,609 counties einploy the assigned counsel systein, and 330 counties employ the contract system. BUREAU OF Justice Statistics, DeP'T OF Justice, CRIMINAL DEFENSE FOR THE POOR 3 (1988). 
Although the Court was able to require the appointment of counsel with a stroke of a pen, it has proven far more difficult to enforce Gideon's mandate in practice. Indigent-defense providers currently are experiencing a crisis that has severely compromised the Sixth Amendment guarantee that adequate representation be provided in all criminal proceedings. Three factors-criminal justice pohicy, the econoiny, and the "war on drugs"-have combined to strain the level and quality of indigent-defense representation. ${ }^{33}$ The root of the crisis is that increased efforts to fight crime have clogged the courts and have swainped imdigent-defense attorneys with unmanageable caseloads. While state legislatures have willingly appropriated additional resources to fight crime, inost have neglected to increase funding to support the other components of the criminal justice systen: prosecution, the courts, and public defense. $^{34}$ According to a 1990 Department of Justice study, $42.8 \%$ of national expenditures on the criminal justice system were spent on police, $33.6 \%$ were spent on corrections, $12.5 \%$ on the courts, and $7.4 \%$ on prosecution. ${ }^{35}$ In contrast, a mere $2.3 \%$ of the total criminal justice expenditures were devoted to legal services for indigent defendants. ${ }^{36}$

Reports of overburdened and underfunded indigent-defense prograins are all too common. In late 1992, the state of New Jersey eliminated $\$ 3.05$ million from the budget of the Department of the Public Advocate; $\$ 2.9$ million of that amount came out of the public defender's budget. ${ }^{37}$ In Connecticut, the state Civil Liberties Umion filed suit against the governor and the Public Defender Services Commission, alleging that the state's inadequate funding of the indigent-defense system violated the constitutional right to counsel because public defenders had handled an average of 1,045 cases apiece during the previous year. ${ }^{38}$ One New Orleans public

33. Klein \& Spangenberg, supra note 4 , at 3 .

34. Id. at 5.

35. BurEau of Justice Statistics, U.S. DEP't OF Justice, SOURCEBook OF CRIMINAL JUSTICE STATISTICS 3 (1992). Approximately $\$ 74$ billion was spent overall in administering the criminal justice system. $I d$. at 2 .

36. Id. at 3.

37. Rocco Cammarere, Public Defender Funding Deadline Passes with No Solution, NEW JERSEY LAW., Jan. 4, 1995, at 3. The person who had served as Public Advocate had resigned several months earlier in "disgust" to protest these budget reductions. New Jersey Shuts Down Its Advocate; Was Unique in Nation, NAT'L L.J., July 20, 1992, at 3.

38. Lynne Tuoly, CCLU Suit Lays Bare a Public Defense System in Crisis, HARTFORD COURANT, Jan. 8, 1995, at A1. 
defender's caseload was so excessive that he sued himself, arguing that his caseload made effective client representation an impossibility. Agreemg with the defender, the trial judge ruled that "[n]ot even a lawyer with an $S$ on his chest could effectively handle this docket." ${ }^{\prime 39}$ The defender had represented 418 clients in seven months; 70 cases were pending trial. ${ }^{40}$

Other anecdotal evidence further demonstrates that governmental spending on the criminal justice systein las not kept pace with the increase in arrests and prosecutions. A brief survey reveals that indigent-defense programs are among the first services to be cut from state and local budgets during difficult economic times. For example, the municipal government of Orange County, California, eliminated $\$ 3.7$ million from its indigent-defense services budget-a $29 \%$ reduction -in an atteinpt to bail out of its highly publicized bankruptcy. ${ }^{41}$ This budget cut forced a consolidation of the county public defender's office and drastically reduced the amount of funds available for retaining private defense attorneys. ${ }^{42}$ In contrast, the next largest budget cut by percentage was a $17.8 \%$ cut from the liuman resources department budget-a reduction of only $\$ 800,000 .^{43}$ In Phoenix, after the county government rebuffed the defender's request for a funding imcrease, the local newspaper ran a byline that encapsulates the public's attitude toward funding indigent-defense programs: "Defender's Office Told to Stand in Lime."44 Finally, the Governor of New York called recently for a cut of $\$ 13.8$ million in state funding for legal aid societies and public defenders-a $35 \%$ reduction; the Governor left intact a $\$ 20.8$ million aid program for local prosecutors and proposed a four-year $\$ 476$ million prison expansion program. ${ }^{45}$ It is clear, therefore, that an increasingly cost-conscious public is unwill-

39. State v. Peart, 621 So. $2 d 780,789$ (La. 1993).

40. Id. at 784 (citing trial court record).

41. Dan Weikel \& Julie Marquis, Programs for Poor Suffer Deepest Cuts, L.A. TIMES, Dec. 23, 1994, at A1, A9.

42. Rene Lynch, Public Defenders Take on Bigger Caseload, L.A. TIMES, Jan. 9, 1995, at B1, B7. The county retained private defense attorneys when a conflict preempted the public defender office from providing representation. Id. at B7.

43. Weikel \& Marquis, supra note 41, at A9.

44. Chris Fiscus, Defender's Office Told to Stand in Line, Phoenix GAZETTE, Dec. 8,1994 , at B1.

45. Gary Spencer, Pataki Backs Courts Budget of \$I Billion; Surcharge on Awards Sought to Fund Increase, N.Y. L.J., Dec. 18, 1995, at 1. 
ing to provide desperately needed funds to support indigent-defense programs.

\section{The Doctrine of Malpractice IMMUNITY as APPliEd to PUBLIC DEFENDERS AND COURT-APPOINTED COUNSEL}

The first case addressing malpractice immurity for public defenders or court-appointed counsel did not occur until $1975 .{ }^{46}$ Since that time, the majority of state courts considering this issue have determined that imdigent-defense counsel are ineligible to receive immunity from inalpractice because they serve the same function and purpose in the criminal justice system as privately retained attorneys; both types of lawyers are legally and ethically obligated to provide a competent defense for their clients. The Supreme Court's rulings on civil riglits actions brought under 42 U.S.C. § 1983 also support this view. ${ }^{47}$ In recent years, however, several state courts have broken from the traditional no-immunity rule and demonstrated a willingness to grant either qualified or absolute immunity.

\section{A. The Traditional No-Immunity Rule in Theory and in Practice}

The dominant rule anong state courts lias been that public defenders and court-appointed counsel should be denied nialpractice immunity and should be held to the same professional standards as private attorneys. The first courts to consider this issue, the Supreme Courts of Connecticut and of Pennsylvaria, declined to grant malpractice immunity in Spring $v$. Constantino ${ }^{48}$ and Reese v. Danforth, ${ }^{49}$ respectively. Neither court could identify a principled legal basis for differentiating between the representation provided by a public defender and that provided by a private attorney. Basing their reasoning on these seminal cases, courts in

46. Spring v. Constantino, 362 A.2d 871 (Conn. 1975).

47. See cases cited infra notes 71-75 and accompanying text.

48. 362 A.2d 871 (Conn. 1975). The plaintiff in Spring was a criminal defendant who sned her attorney for negligence; the attorney was a public defender who had been appointed to defend her at trial. In her complaint, the plaintiff alleged that her attorney had failed to advise her of bail procedures that could have secured her release from prison. Id. at 873 .

49. 406 A.2d 735 ( $\mathrm{Pa}$. 1979). In Reese, the plaintiff brought an action in trespass alleging negligent representation against her former attorney, a county public defender. The plaimtiff had been confined involuntarily in a psychiatric hospital in a proceeding brouglit pursuant to the state mental health and mental retardation statute. Id. at 736-37. 
four other states-Michigan, ${ }^{50}$ Florida, ${ }^{51}$ Indiana, ${ }^{52}$ and New Jersey ${ }^{53}$-have explicitly adopted some form of the no-immunity rule. $^{54}$

In refusing to extend immunity to public defenders and courtappointed counsel, the no-immumity courts have consistently posited that these attorneys have the same function and purpose in the criminal justice systenı as private attorneys. Although cognizant that an indigent-defense attorney serves the public interest in representing poor defendants, these courts have ruled that his "role does not differ froin that of privately retained counsel." 55 Indigent-defense attorneys assume the same "duties as an officer of the court and to an individual chent" as private attorneys: They are ethically and professionally obligated to conduct a "primcipled and fearless" defense that is not deterred by the prospect of hability. ${ }^{56}$ Acting as "an adversary [of the state]" when defending his chent, ${ }^{57}$ the defender inust fulfill the "overriding duty of zealous representation of a chent's interest" who once appointed owes a duty only to his chent, the indigent defendant." In sum, the defender assumes "all the obligations and protections attendant upon a private attorney-client relationship except one: the public pays his fee." ${ }^{60}$ It is only appropriate

50. See Donigan v. Finn, 290 N.W.2d 80, 81 (Mich. Ct. App. 1980) (finding that court-appointed counsel are not immune from nualpractice liability when defending an indigent chent).

51. See Windsor v. Gibson, 424 So. $2 d 888,889$ (Fla. Dist. Ct. App. 1982) (holding that the doctrine of judicial immunity does not preclude an action aganist the office of the public defender by a former chent).

52. See White v. Galvin, 524 N.E.2d 802, 804 (Ind. Ct. App. 1988) (holding that a public defender is not a public employee as defined in the state tort claims act).

53. See Delbridge v. Office of Public Defender, 569 A.2d 854, 865 (N.J. Super. Ct. Law Div. 1989) (finding that public defenders are not immune from a claim of legal nualpractice). Delbridge is a soinewliat atypical no-immunity case because it also held that the public defender should be considered an "einployee" under the state tort claims act for indemnification purposes. Id. at 869-71. None of the other no-immunity cases classify the indigent-defense attorney under this mbric.

54. This section will focus primarily on the arguments made in Spring and Reese because the other no-immunity courts have based their reasoning on these seminal cases.

55. Windsor v. Gibson, 424 So. 2d 888, 889 (Fla. Dist. Ct. App. 1982).

56. Spring v. Constantino, 362 A.2d 871, 875 (Conn. 1975); see also Delbridge, 569 A.2d at 866 .

57. Spring, 362 A.2d at 875 (citing State v. Jackson, 294 A.2d 517 (Conn. 1972), cert. denied, 409 U.S. 870 (1972)).

58. Reese v. Danforth, 406 A.2d 735, 738 (Pa. 1979).

59. Windsor, 424 So. $2 \mathrm{~d}$ at 889.

60. Reese, 406 A.2d at 739. 
that the indigent-defense attorney be held liable for tortious conduct committed in the scope of his professional duties. ${ }^{61}$

Accepting the doctrinal starting point that public defenders and court-appointed counsel must function as privately retained attorneys in our adversary system, the no-immunity rule also rejects the use of state tort immunity statutes as a means of shielding indigent-defense attorneys from liability. ${ }^{62}$ Tort immunity statutes generally prevent private individuals froin suing public officials in their individual capacities provided that their actions are neither wanton nor willful. ${ }^{63}$ As one court stated, "Control, or the right to control, is a precondition necessary to establish vicarious liability in tort." ${ }^{64}$ Yet, because the no-immunity position assunies that the mdigent-defense attorney opposes the state's interest when representing a criminal defendant, state control does not exist.

The Connecticut Supreme Court's ruling in Spring illustrates the no-immunity rule's refusal to apply tort immunity statutes in order to insulate public defenders from tort liability. The tort immunity statute in Spring immunized any "state officer or en1ployee" from personal hability for actions taken within the scope of his einployment as long as the actions were neither wanton nor willful. ${ }^{65}$ The defendant, a public defender, argued that his acts

61. Delbridge v, Office of Public Defender, 569 A.2d 854, 866 (N.J. Super. Ct. Law Div. 1989); see also Reese, 406 A.2d at 740 (finding that denying an indigent the tort relief that is available to the paying client would distinguish between groups of plaintiffs based on economic status).

62. The Spring court also lield that the pnblic defense of a client could not be construed as a sovereign or governmental act. Spring, 362 A.2d at 875 .

63. See Spring, 362 A.2d at 876-77. For an example of a state tort immunity statute, see the statute considered in Vick v. Haller, 512 A.2d 249, 252 (Del. Super. Ct. 1986), affd in part, 522 A.2d 865 (Del. 1987), and Browne v. Robb, 583 A.2d 949 (Del. 1990), cert. denied, 499 U.S. 952 (1991), discussed infra notes 87-94 and accompanying text. Under the Delaware statute, an indigent-defense attorney claiming immunity must prove that the act or omission complained of (1) arose out of and in connection with the performance of an official duty; or (2) was done in good faith and in the belief that the public interest would best be served thereby; or (3) was done without gross or wanton negligence. Vick, 512 A.2d at 252 (applying DEL. CODE ANN. tit. 10, \& 4001 (Supp. 1994)).

64. White v. Galvin, 524 N.E.2d 802, 804 (Ind. Ct. App. 1988).

65. The relevant part of this statute stated:

No state officer or employee slall be personally liable for damage or injury, not wanton or wilful, caused in the performance of his duties and within the scope of his employinent. Any person having a complaint for such damage or injury shall present it as a claim against the state ....

Spring, 362 A.2d at 875 (quoting CONN. GEN. STAT. ANN. \& 4-165 (West 1988)).

The statute defining state officers and employees stated: 
and omissions in the context of the attorney-client relationship slould qualify him as a "state employee" within the purview of the tort immunity statute. ${ }^{66}$ Rejecting this argument, the Spring court held steadfast to the foundational assumption that a public defender serves the same functional purpose as a private attorney. Once the attorney-client relationship begims, the status of the public defender is "that of an independent contractor rather than of an einployee [of the state]"; ${ }^{\prime 67}$ the defender acts on behalf of his client "as if he had been employed and retained by the defendant whom he represents." 68 The state's relationship witl the public defender, moreover, does not alter the latter's responsibilities to his client. As a different court observed, the state's sole connection to the defender is in paying his fee; it is the court, not the state, that appoints the defender. ${ }^{6}$ Thus, because the "independence of the public defender and his freedoin from entanglement with the state is a key constitutional underpinning of . . . the public defender system," ${ }^{70}$ granting immunity vis-à-vis a tort immunity statute would distinguish unfairly between plaintiffs based on their economic status.

Federal decisions on civil rights clanns brought by indigent clients under 42 U.S.C. $\S 1983^{71}$ against their public defenders provide additional support for the no-immunity rule. In Polk County v. Dodson, the Supreme Court specifically held that a public defender serving as counsel for an indigent defendant did not act "under color of state law" for purposes of section $1983 .{ }^{72}$ This holding reinforces the no-immunity idea that the law should treat defenders like private attorneys, not like state employees. The

[E]very person elected or appointed to or einployed in any office, position or post in the state government, whatever his title, classification or function and whether he serves with or without remuneration or coinpensation.

Id. at 876 (quoting CONN. GEN. STAT. ANN. § 4-141. (West 1988)).

66. Id. at 877 .

67. Id. at 878 .

68. Id.

69. White v. Galvin, 524 N.E.2d 802, 804 (Ind. Ct. App. 1988).

70. Spring, 362 A.2d at 878 .

71. The text of 42 U.S.C. $\& 1983$ (1988) states:

Every person who, under color of any statute, ordinance, regulation, custom, or usage, of any State or Territory of the District of Columbia, subjects or causes to be subjected, any citizen of the Umited States or other person with the jurisdiction thereof to the deprivation of any rights, privileges, or immunities secured by the Constitution and laws, shall be liable to the party imjured in an action at law, suit in equity, or other proceeding for redress.

72. 454 U.S. 312,325 (1981). 
Court also held in Ferri v. Ackerman that section 1983 does not protect counsel appointed to represent indigent defendants in federal court from state court inalpractice suits. ${ }^{73}$ Once again mirroring the rationale of the no-immunity rule, the Court found that the public defender's principal responsibility was to "serve the undivided interests of his client" rather than the interests of "the public at large..74 In a phrase reminiscent of Spring and Reese, the Ferri Court held that immunity was improper because an indispensable element of the public defender's responsibilities was the "ability to act indepeudently of the Government and to oppose it in adversary litigation."75

\section{B. The Emergence of Qualified and Absolute Immunity}

In recent years, several state courts have strayed from the nominiunity rule and have granted some forn of malpractice immunity to indigent-defense counsel. In particular, two forns of immunity have appeared on the criminal justice horizon: qualified (or discretionary) immunity and absolute immunity. Under qualified minunity, a public defender or court-appointed attorney is immune from suit for all "discretionary" acts or ormssions made in the course of executing her official duties. Under absolute immunity, an attorney is completely immune for all acts and omissions made in the course of executing her official duties.

1. Qualified Immunity. The first court to grant qualified immunity, a New York Supreme Court in Scott v. City of Niagara Falls, ${ }^{76}$ disagreed sharply with the analyses of Spring and Reese. The Scott court found that the unique nature of the public defender's duties gave rise to several pohicy reasons that justified, if not required, the abandonment of the no-immunity rule. The Scott court argued that a public defender, unlike a privately retained attorney, was often "assigned an overwhelming nuniber of cases" and thus was forced to "effectively allocate [her] limited time and resources to those matters which ni [her] judgment have a realistic chance for success. ${ }^{.77}$ In turn, the constant prospect of

\footnotetext{
73. 444 U.S. 193 (1979).

74. Id. at 204 .

75. Id.

76. 407 N.Y.S.2d 103 (N.Y. Sup. Ct. 1978).

77. Id. at 105 .
} 
potential liability arising out of every frivolous inalpractice claim would impair the public defender office's recruitment of capable attorneys. $^{78}$ In light of these concerns, the Scott court reasoned that a grant of malpractice immunity was consistent with the public defender's duty to provide competent and zealous representation, especially because the courts or bar associations could remove the public defender if sle "fail[ed] to perform [her] duties in a responsible fashion.",79

Courts in three other states-Nevada, Delaware, and Vermont-have granted qualified immunity since $S$ cott. ${ }^{80}$ In two terse opinions, the Nevada Supreme Court granted qualified immunity to public defenders and court-appointed counsel pursuant to the Nevada tort immunity statute for state einployees. ${ }^{81}$ Like Scott, both Nevada cases inplicitly rejected the arguments that undergird the no-immunity rule in Spring and Reese. In Ramirez v. Harris, ${ }^{82}$ the Nevada Supreine Court ruled that because public defenders fit the statutory definition of a "public officer," they could not be sued for "malpractice arising out of discretionary decisions that [were] made pursuant to their duties as public defenders." 84 While this holding does not explicitly foreclose an indigent client in Nevada froin suing a public defender for intentional or reckless

78. Id.

79. Id.

80. In Briggs v. Lawrence, a California court of appeal adopted a rule that incorporates aspects of both qualified immunity and the no-immunity rule. 281 Cal. Rptr. 578 (Cal. Ct. App. 1991). In Briggs, the court held that a salaried full-time public defender is a "public employee acting in the scope of his or her employment within the meaning of the California Tort Claims Act." Id. at 586. The court also held, however, that the public defender would not be immune from hability for malpractice. Id. Rather, the only "practical issue" addressed by the Briggs case was "whether the defendants may look to the public entity for defense and for indemnification." Id.

81. See Morgano v. Smith, 879 P.2d 735, 737 (Nev. 1994); Ramirez v. Harris, 773 P.2d 343, 344 (Nev. 1989). Under Nevada's tort immunity statute, no action may be brought against an officer of the state which is

[b]ased upon the exercise or perfornance or the failure to exercise or perform a discretionary function or duty on the part of the state or any of its agencies or political subdivisions or of any officer, employee or immune contractor of any of these, whether or not the discretion involved is abused.

Nev. Rev. Stat. ANN. $\S 41.032$ (2) (Michie Supp. 1993). This statute was cited in both Nevada cases. See Morgano, 879 P.2d at 736-37; Ramirez, 773 P.2d at 344.

82. 773 P.2d at 343.

83. Section 41.0307(4)(b) of the Nevada Revised Statutes defines "public officer" to include "[a] public defender and any deputy or assistant attorney of a public defender." Nev. ReV. Stat. ANN. \& 41.0307(4)(b) (Michie Supp. 1993).

84. Ramirez, 773 P.2d at $344-45$. 
acts of malpractice, it does prevent her from suing for neghigent representation. ${ }^{85}$ The Nevada Supreme Court later used the same rationale in Morgano v. Smith to extend the same degree of qualified immunity to court-appointed counsel. ${ }^{86}$

In Vick v. Haller ${ }^{87}$ and Browne v. Robb, ${ }^{88}$ the Delaware courts also held that public defenders and court-appointed counsel should be considered state employees and thus enjoy qualified immunity under the state tort claims statute. Like the Nevada cases, the Vick court held in a brief opimion that the state tort claims act immunized the public defender from malpractice hability. ${ }^{89}$ The Browne court, however, considered the Delaware tort claims statute at greater length. To claim immunity under this statute, an indigent-defense attorney must prove that the act or omission complained of (1) arose out of and in connection with the performance of an official duty; (2) was done in good faith and in the belief that the public interest would best be served thereby; or (3) was done without gross or wanton neghigence. ${ }^{90}$ The Browne court found that this tort immumity statute was "imtended to discourage lawsuits [that] might create a chilling effect on the ability of public officials or employees to exercise their discretionary authority." ${ }^{" 91}$ Observing that indigent-defense counsel caumot refuse to take their chents' cases, ${ }^{92}$ the Browne court held that "a failure to recognize the statutory and common law principles of qualified immunity would necessarily 'chill' the private contract system" used to provide mdigent-defense services im Dela-

85. Id. at 345 .

86. 879 P.2d 735, 737 (Nev. 1994) (finding that court-appointed counsel were immune from malpractice for negligence arising out of their discretionary decisions). At the time, the statnte defining "public officer" and "officer" had been enlarged to include not only public defenders but also "attorney[s] appointed to defend a person for a limited duration with limited jurisdiction." Id.

87. 512 A.2d 249, 252 (Del. Super. Ct. 1986), affd in part, 522 A.2d 865 (Del. 1987).

88. 583 A.2d 949 (Del. 1990), cert. denied, 499 U.S. 952 (1991).

89. Vick, 512 A.2d at 252. In affirming the Vick court's decision, the Delaware Supreme Court reiterated that public defenders are indeed state employees within the meaning of the state tort claims act. Browne, 583 A.2d at 951 (citing Vick v. Haller, 522 A.2d 865 (Del. 1987) (unpublislied opinion)).

90. Vick, 512 A.2d at 252 (applying DEL. CODE ANN. tit. 10, § 4001 (Supp. 1994)).

91. Browne, 583 A.2d at 952 (quoting Doe v. Cates, 499 A.2d 1175, 1181 (Del. Super. Ct. 1985)).

92. Browne, 583 A.2d at 952 (acknowledging that "contract lawyers do not lave the ability, which they ordinarily would possess in the marketplace, to reject such clients or cases"). 
ware. ${ }^{93}$ The Browne court therefore determined that the relationship between court-appointed attorneys and their indigent clients necessitated that the former be entitled to qualified immunity as state einployees under the state tort immunity statute. ${ }^{94}$

Following the lead of the Nevada and Delaware courts, the Vermont Supreme Court held recently in Bradshaw v. Joseph that a public defender is a state employee under state law and cannot be sued for negligence while acting within the scope of his enployment. ${ }^{95}$ The Bradshaw court set forth a detailed rationale for granting qualified immunity to public defenders $-\mathrm{a}$ rationale that other state courts are likely to consult when considering a departure from the no-immunity rule in the future. In Bradshaw, a disgruntled former client sued his public defender for negligence. ${ }^{96}$ In response, the defender countered that he was considered a state employee and thus was within the ambit of the tort immunity statute for state employees. ${ }^{97}$ Under Vermont law, the definition of a state employee "includes any elective or appointive officer or employee within the legislative, executive or judicial branclies of state government or any former such einployee or officer." ${ }^{\text {"98 }}$ While public defenders are not explicitly referred to as state employees, the Bradshaw court nevertheless posited that the language of the statute, particularly the use of the words "includes" and "witlout limitation," signified a legislative intent "to

93. Id. at 952 .

94. Id. at 951-52. Although the Browne court did not explicitly refer to court-appointed counsel as state employees, its holding that these attorneys have qualified immunity under the state tort claims act has the effect of categorizing them under this rubric. Id.

95. Bradshaw v. Joseph, 666 A.2d 1175, 1176 (Vt. 1995).

96. Id. at 1175 . The plaintiff in Bradshaw alleged that he had suffered damages as a result of his public defender's negligence. The plaintiff had been charged with sexual assault; the court had set bail at $\$ 10,000$. Yet, because the plaintiff could not meet this requirement, he remained incarcerated. The public defender then successfully moved that the plaintiff's bail be reduced to $\$ 5,000$. The incarcerated plaintiff, however, alleged that he had never been informed of this bail reduction-an amount that he could have met. As a result of this alleged failure to notify, the plaintiff remained incarcerated until lie was eventually acquitted. Id. at 1776 . The Bradshaw court did not mention low long the plaintiff was imprisoned.

97. Id. at 1176 . The tort immunity statute states that "when any act or oirission of a state employee, as defined in 3 V.S.A. $\S 1101$, 'is believed to have caused damage to property, injury to persons, or death, the exclusive right of action shall lie against the state' and suit against the employee is prohibited." Id. (citing VT. STAT. ANN. tit. 12, § 5602 (1995)).

98. Id. (emphasis omitted) (citing VT. STAT. ANN. tit. 3, § 1101(b) (1995)). 
enlarge the categories of positions that fall within the definition of 'state employee." "999 The Bradshaw court also posited that the origin and function of the public defender's office as well as its source of funding suggested that a public defender should be considered a state einployee: the legislature had created the offices of the public defender and defender general; public defenders provided legal representation at state expense; and the state provided coinpensation to both public defenders and the defender general. ${ }^{100}$ The Bradshaw court concluded that the defender should be considered a state einployee and thus was entitled to qualified immunity for "acts or omissions occurring within the scope of [his] einployment." "101

2. Absolute Immunity. In the wake of qualified immunity, a far nore encompassing form of malpractice liability has appeared-absolute immunity. Whereas qualified immunity protects indigent-defense attorneys from malpractice for negligent acts or omissions, the doctrine of absolute immunity protects attorneys from liability for all job-related acts or omissions, including those that result from recklessness, gross incompetence, or intentional misconduct. And while the doctrine of qualified immunity rests primarily on finding that an indigent-defense attorney qualifies as a state employee under a tort immumity statute, the doctrine of absolute immumity relies almost exclusively on public policy concerns.

Courts in two states, New Mexico and Minnesota, have granted absolute immunity to indigent-defense counsel. In Herrera $v$. Sedillo, ${ }^{102}$ the New Mexico Court of Appeals extended absolute immunity to court-appointed attorneys pursuant to a state statute, the Indigent Defense Act. The defendant in Herrera was an attorney appointed by the court and "retained under contract to the Public Defender" in order to provide representation in a criminal

99. Id. According to the Bradshaw court, the statute's list of eight categories of state employees, which included "state's attorneys," was not meant to be an exhaustive list. Id. (stating that the "enumeration of positions is "without limitation" ").

100. Id. at $1176-77$.

101. Id. at 1177. The Bradshaw court also addressed several of the policy arguments for and against malpractice immunity. These arguments will be considered in greater detail infra Section II(B)(2) and Part III.

102. 740 P.2d 1190 (N.M. Ct. App. 1987). 
case. ${ }^{103}$ There was a dispute, however, whether this attorney was appointed pursuant to the Indigent Defense Act or another state statute, the Public Defender Act. Under the Indigent Defense Act, a court-appointed attorney enjoyed absolute immunity: "No attorney assigned or contracted with to perform services under the Indigent Defense Act ... shall be held liable in any civil action respecting his performance or nonperformance of such services." 104 In contrast, the Public Defender Act neither provided for nor denied immunity. ${ }^{105}$ Without deciding under which statute the defendant was acting, the Herrera court held that "the immunity granted to attorneys appointed under the Indigent Defense Act" also applied to appointed counsel under contract to the public defender. ${ }^{106}$ The Herrera court could not discern a reason why the legislature would have drawn a distniction between court-appointed attorneys and public defenders. ${ }^{107}$

Clarifying the Herrera rationale, the New Mexico Court of Appeals lield ni Coyazo v. State ${ }^{108}$ that both court-appointed counsel and public defenders enjoy absolute immunity fronı inalpractice. Whereas a court-appointed attorney is protected under the state Indigent Defense Act, a public defender is protected as a "public eniployee" under the state Tort Claims Act. More importantly, the Coyazo court provided several policy reasons as support for its absolute-immunity stance. First, the court stated that absolute immunity encourages attorneys to participate as court-appointed coimsel because they are "assured of not having to deal with the threat of civil litigation atop a practice [that] consists of clients they are not free to clioose or refuse." ${ }^{109}$ Second, absolute immunity allows counsel to "exercise fully independent professional judgnient and discretion without fear of 'Monday nıorning quarterbacking' in a civil context."110 Third, absolute inımunity allows private attorneys to lower insurance costs, which helps indigent defendants by encouraging more attorneys to participate as

103. Id. at 1191.

104. Id. (citing N.M. STAT. ANN. \& 31-16-10 (Michie Supp. 1984)).

105. Id.

106. Id.

107. Id.

108. 897 P.2d 234, 238 (N.M. Ct. App. 1995).

109. Id. at 240 .

110. Id. 
indigent-defense counsel. ${ }^{111}$ Fourth, the Coyazo court candidly stated that absolute immunity saves taxpayer money: "[I]mmunity of necessity protects the public treasury."112

Between the time of the Herrera and Coyazo decisions, the Minnesota Supreme Court granted absolute immunity to public defenders in Dziubak v. Mott. ${ }^{113}$ A controversial decision relying solely on policy grounds, the Dziubak decision sparked intensive analysis and harsh criticism from several commentators. ${ }^{114}$ In ruling that public defenders should be completely immune from suit for legal malpractice, the Dziubak court articulated a policy-based rationale that conflicts with almost every aspect of the no-immunity rule. First, the Dziubak court held that significant differences between public defenders and privately retained counsel warranted different treatment under the law. As the Browne court also argued, ${ }^{115}$ the Dziubak court emphasized that a public defender was unable to reject a client and was obligated to represent whoinever was assigned to lier, regardless of caseload size or the degree of difficulty presented by the case. ${ }^{116}$ In contrast, a private attorney could clioose to decline representing a client for a variety of reasons, mcluding the merits of the case, her current caseload, or even the client's personality. ${ }^{117}$ Citing a study finding that Minnesota public defenders were "working substantially above capacity with insufficient time to devote to their cases and their clients," the court concluded that this inability to refuse clients was a crucial difference justifying the extension of immunity to public defenders. ${ }^{118}$

111. Id.

112. Id.

113. 503 N.W.2d 771 (Minn. 1993).

114. See Erika E. Pedersen, Note, You Only Get What You Can Pay For: Dziubak v. Mott and Its Warning to the Indigent Defendant, 44 DEPAUL L. REv. 999, 1030-47 (1995); David J. Richards, Note, The Public Defender Defendant: A Model Statutory Approach to Public Defender Malpractice Liability, 29 VAL. U. L. REv. 511, $538-47$ (1994); Jeffrey H. Rutherford, Comment, Dziubak v. Mott and the Need to Better Balance the Interests of the Indigent Accused and Public Defenders, 78 MiNN. L. REv. 977, 995-1005 (1994).

115. See supra notes $92-93$ and accompanying text.

116. Dziubak, 503 N.W.2d at 775.

117. Id.

118. Id. The study cited was The Spangenberg Group, Weighted Caseload Study for the STATE of MinNesota BoARD of Public Defense 20 (1991). 
Second, the Dziubak court found another crucial distinction in the gross disparity in funding between public defenders and privately retained counsel. While a private attorney was limited only by the client's ability to pay, the court observed that public defender offices generally operate under fixed, insufficient budgets. ${ }^{119}$ To support this finding, the court cited a study concluding that the increasing crime rate, the depressed economy, and an insufficient budget had caused public defender caseloads to grow dramatically. ${ }^{120}$ Reasoning that the public defender had little control over such factors, the court lield that to subject lier to inalpractice suits for acts or omissions caused by circumstances beyond her control would be "an unfair burden."

Third, the Minnesota Supreme Court adopted a utilitarian policy analysis to justify the extension of malpractice immunity to public defenders. It asserted that immunity would allow the public defender to conserve her time, energy, and money in order to best serve the indigent population. ${ }^{122}$ In addition, the Dziubak court found that immunity would aid in the contmued recruitment of attorneys to serve as public defenders by minimizing the fear of malpractice exposure. ${ }^{123}$ According to the court's reasoning, the extension of immunity would ensure that indigent-defense resources would be used "for the defense of the accused, rather than diminished through the defense of public defenders against civil suits for malpractice."124 Thus, the Dziubak court concluded that the extension of immunity would conserve limited resources to provide "an effective defense to the greatest number of indigent defendants." $" 125$

\section{A CRITIQUe OF MALPRACTICE IMMUNITY}

Despite its recent popularity annong state courts, the doctrine of inalpractice immumity remams an illegitimate and ineffective response to the crisis in indigent defense. The courts that have broken froin the no-immunity rule fail to recognize that malpractice

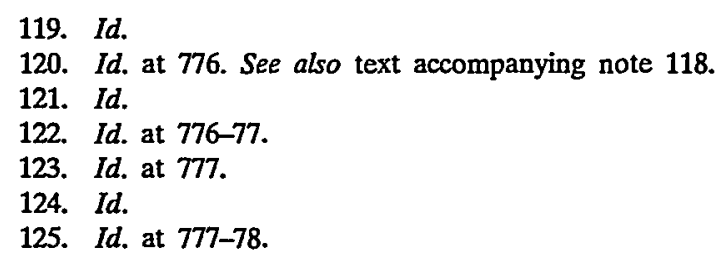


immunity has several glaring, if not indefensible, flaws. In an effort to reveal these legal and policy-based weaknesses, this Part argues that inalpractice immunity undermines core principles of our criminal justice system, disregards the indigent defendant's rights, and has tremendous costs not only for indigent defendants but also for the legal profession and society as a whole. Finally, this Part exposes inalpractice immunity for what it is: an attempt to protect the public treasury at the imdigent defendant's expense.

\section{A. Malpractice Immunity Undermines Core Principles of Our Criminal Justice System}

1. The Adversary System. The first crucial defect with malpractice immunity is its incompatibility with our adversary system of criminal justice. The linclipin of our criminal justice system is the idea that the state and the criminal defendant must function as adversaries. ${ }^{126}$ Reflecting this basic premise, the Model Rules of Professional Conduct state that "[the] lawyer should act with commitinent and dedication to the interests of the client and with zeal in advocacy upon the client's behalf."127 Applying this principle to criminal defendants who are unable to hire their own lawyers, the Gideon Court found that there could be no justice unless the accused has the services of an effective and independent advocate. ${ }^{128}$ The no-immunity courts have kept with Gideon's spirit and properly determined that an indigentdefense attorney must function purely as a private attorney concerned with representing his client. ${ }^{129}$ The indigent-defense attorney, like his privately retained counterpart, bears the same "overriding duty" to zealously represent his chent's interests; the only salient difference is that the public pays the lawyer's fee. ${ }^{130}$

126. The Gideon Court itself acknowledged this fact: "[The] government hires lawyers to prosecute and defendants who have the money hire lawyers to defend." Gideon v. Wainwright, 372 U.S. 335, 344 (1963).

127. MOdEL RULES OF PROFEsSIONAL CONDUCT Rule $1.3 \mathrm{cmt}$. (1992); see also MODEL RULES OF PROFESSIONAL CONDUCT Preamble (1992) ("As advocate, a lawyer zealously asserts the client's position under the rules of the adversary system.").

128. Gideon, 372 U.S. at 344 (finding that "in our adversary system of criminal justice, any person haled into court, who is too poor to hire a lawyer, cannot be assured a fair trial unless counsel is provided for him"); see also Holloway v. Arkansas, 435 U.S. 475, 489 (1978).

129. See Reese v. Danforth, 406 A.2d 735, 739 (Pa. 1979); see also supra Section II(A) (discussing the no-immunity rule).

130. Reese, 406 A.2d at 738-39. 
This view finds additional support in the Supreme Court's civil rights rulings under 42 U.S.C. \& 1983, which determined that public defenders necessarily oppose the government as adversaries $^{131}$ and do not act under color of state law in their official capacities. ${ }^{132}$

Requiring indigent-defense counsel to function as private attorneys also accords with the legal profession's sense of justice and fairness. Few lawyers would question that an indigent defendant should have the same rights and privileges that a paying chent has in the context of the attorney-client relationship. Like his nonindigent counterpart, an indigent defendant should have ultimate control in directing his defense and in choosing how to plead. ${ }^{133}$ One therefore would expect an indigent chient to have all of the prerogatives subsumed in the right to counsel, nicluding the right to sue for nialpractice.

The grant of malpractice immunity, however, destroys this crucial assumption. By definition, inalpractice immunity protects indigent-defense attorneys from liability by taking from indigent defendants a right that nonindigent defendants retain. In doing so, the immunity courts concede that indigent defendants are entitled only to a lawyer who is not legally and professionally accountable to them. ${ }^{134}$ Under this view, a public defender or court-appointed attorney is no longer the theoretical equivalent but an inferior version of a private defense lawyer. Imphicitly condoning a lesser standard of criminal representation for indigent defendants, this result is inconsistent witl Gideon's charge that all criminal defendants should have the services of a zealous and effective advocate. Courts inevitably weaken the vitality of the adversary system when they take this position.

Furthermore, no set of policy reasons justifies departing froin the doctrinal starting point that an indigent-defense attorney functions as a private lawyer. The Scott, Browne, and Dziubak courts argued that policy reasons, such as the defender's inability to refuse a case, the gross underfunding of indigent-defense programs,

131. See supra notes 73-75 and accompanying text.

132. See supra notes 71-72 and accompanying text.

133. See, e.g., Miller v. Angliker, 848 F.2d 1312, 1322 (2d Cir.), cert. denied, 488 U.S. 890 (1988) (finding that the defendant, not his attorney, has the right to decide whether to plead guilty, not guilty, or not guilty by reason of imsanity).

134. The issue of professional accountability is further discussed infra Section $\operatorname{III}(\mathrm{A})(2)$. 
and the fear of discouraging attorneys from taking indigent-defense cases, justify an abandonment of the no-immunity rule. ${ }^{135}$ Such policy considerations, however, are an illegitimate basis for emasculating a person's Sixth Amendment rights: The costs to the individual and to society are simply too great. As one prominent commentator noted, "An indigent-even one accused of committing heinous crimes-still has the right to the presumption of innocence and to a fair trial im which he can proffer a defense to the charges leveled against him." ${ }^{136}$ Lacking coinpetent legal representation, "an innocent mdividual may be convicted of a crime merely because she happens to be poor."137 In turn, an improper conviction inevitably leads to the imposition of unfair pumshment, including the death penalty. ${ }^{138}$ This result is simply unacceptable in a society such as ours.

Another one of the glaring flaws of courts that grant qualified immunity is their use of state tort immunity statutes as a basis for granting immunity to indigent-defense counsel. Qualified-immunity courts, such as the Nevada and Delaware courts, posit that a lawyer who serves as a public defender or as a court-appointed attorney should be considered a state employee or public official. ${ }^{139}$ These courts are oblivious of the clear ethical contradiction here. A defense attorney cannot serve simultaneously as both an advocate for a criminal defendant and for the state that wants to convict him. On the contrary, the adversary system demands that the attorney have the utmost loyalty to his chent. ${ }^{140}$ Given this conflict, the application of tort immunity statutes to public defenders

135. See supra notes 76-79, 92-93, and 116-121 and accompanying text.

136. Charles J. Ogletree, Jr., An Essay on the New Public Defender for the 21st Century, LAW \& CONTEMP. PROBS. Wimter 1995, at 81, 82.

137. Id.

138. See, e.g., Stephen B. Bright, Counsel for the Poor: The Death Sentence Not for the Worst Crime but for the Worst Lawyer, 103 YALE L.J. 1835, 1837-41 (1994) (discussing how arbitrary results in death penalty cases frequently stem from the inadequacy of counsel); Sue A. Pressley, Texas Prisoner Executed Despite Questions of Guilt; Texans Seem Unmoved by Controversy in Case, WASH. POST, Jan. 5, 1995, at A3 (reporting that the state of Texas may have executed an innocent man).

139. See discussion of Ramirez v. Harris, 773 P.2d 343, 344 (Nev. 1989), Morgano v. Smith, 879 P.2d 735, 737 (Nev. 1994), Vick v. Haller, 512 A.2d 249, 252 (Del. Super. Ct. 1986), affd in part, 522 A.2d 865 (Del. 1987), Browne v. Robb, 583 A.2d 949, 951-52 (Del. 1990), cert. denied, 499 U.S. 952 (1991), and Bradshaw v. Joseph, 666 A.2d 1175 (Vt. 1995), supra Section II(B)(1).

140. See generally MOdel RULes of Professional Conduct Rule $1.7 \mathrm{cmt}$. (1992) (stating that "[1]oyalty is an essential element in the lawyer's relationship to a client"). 
and court-appointed counsel only serves to embitter mdigent clients and to create an irresolvable ethical dilemma for their defense attorneys.

The sole effort to harmonize this contradiction, the Vermont Supreme Court's attempt in Bradshaw v. Joseph, ${ }^{141}$ illustrates the theoretical infirmity of the qualified-immunity rule. ${ }^{142}$ Defending this dual-role concept, the Bradshaw court explained that the "apparent paradox" of categorizing public defenders as state einployees was but "a variant of numerous interbranch conflicts that inlere in our system of separation of powers, including the clear paradox of having the judicial branch decide constitutional challenges to legislative enactments whereas the Legislature appropriates the funds that sustain the judicial brancl.."143 This explanation, lowever, incorrectly assumes that the public defender is part of the judicial branch. On the contrary, the public defender operates mdependently from both the legislative and judicial branches, functioning for all intents and purposes as a private lawyer. ${ }^{144}$ Thus, the classification of a public defender as a state employee cannot be defended as being an inherent conflict in our system of separation of powers.

2. Attorney Accountability to the Client. The doctrine of malpractice immunity obliterates another cornerstone of our adversary system-the idea that attorneys should be held legally and professionally accountable to their clients-and yields perverse results. Qualified and absolute immunity greatly imcrease the risk that indigent clients will receive sub-standard legal representation by allowing most, if not all, acts of attorney incompetence to go unpunished. Under qualified immumity, imdigent-defense attorneys are protected from hability for discretionary acts and omissions made in the course of executing their official duties. ${ }^{145}$ Yet, because almost every aspect of criminal defense work involves a decision that could be considered discretionary, a public defender who provides shoddy representation in a qualified-immunity jurisdiction $^{146}$ has no real fear of malpractice. For instance,

141. 666 A.2d 1175, 1178 (Vt. 1995).

142. The Nevada and Delaware courts, which also view indigent-defense attorneys as state employees or public officials, did not attempt to reconcile this contradiction.

143. Joseph, 666 A.2d at 1178.

144. See supra notes $129-33$ and accompanying text.

145. See Section II(B)(1) for a complete discussion of qualified immunity.

146. Under Delaware law, an indigent client has a slightly greater degree of protec- 
qualified immunity would fully insulate a public defender who fails to raise appropriate defenses or to call necessary witnesses on behalf of his chent. In contrast, a privately retained attorney who commits these errors surely can expect a malpractice suit. As a result, the qualified-immunity rule allows an indigent defendant to sue his attorney only for ministerial or clerical mistakes, such as missing a filing deadline or allowing the statute of limitations to run.

Absolute immumity permits an even inore absurd standard of legal and professional ethics. The New Mexico and Minnesota courts suggest that malpractice immunity actually would help indigent defendants. ${ }^{147}$ This view, however, ignores the obvious fact that absolute immunity makes the indigent-defense attorney completely unaccountable to the client for all acts of incompetence. A public defender could miss filing deadlines, fail to suppress illegally seized evidence, or even forget to appear in court without fear of being held legally and professionally accountable to the client. The Dziubak case itself is a good example of this perverse standard. In Dziubak, an expert witness had misread the toxicology report of the decedent whom the defendant was accused of killing; the defendant's lawyer, a public defender, failed to bring this information to the court's attention. ${ }^{148}$ As a result, the imdigent defendant was convicted wrongly and was incarcerated for fifteen months until exculpatory evidence came to light. Yet, although the chent clearly had suffered as a consequence of the defender's neghigent representation, Dziubak's absolute-immunity rule precluded any suit for malpractice. This standard of unaccountability demeans the idea of professional responsibility in the attorney-

tion from incounpetent representation than in other qualified-immunity jurisdictions because the Delaware tort statute does not provide immunity to an indigent-defense attorney for wanton or willful acts or omissions. See cases cited supra notes 87-94 and accompanying text.

147.

The extension of immunity to public defenders will ensure that the resources available to the pnblic defender will be used for the defense of the accused, rather than diminislied through the defense of public defenders against civil suits for malpractice. Immunity will conserve these resources to provide an effective defense to the greatest number of indigent defendants.

Dziubak v. Mott, 503 N.W.2d 771, 777-78; see Coyazo v. State, 897 P.2d 234, 240 ("Indigent defendants as a class are benefited because more attorneys are encouraged and likely to participate in indigent defense work.")

148. Dziubak, 503 N.W.2d at 773 n.2. 
client relationship and effectively leaves the indigent defendant at the inercy of his attorney.

\section{B. Malpractice Immunity Disregards the Rights of the Indigent Criminal Defendant}

The second major flaw with malpractice immunity for indigent-defense counsel is its complete disregard for the rights of the indigent criminal defendant. The immunity courts fail to understand that the right to sue for malpractice is the indigent defendant's sole guarantee that his appoimted attorney will mount a competent, vigorous defense. It is self-evident that the right to sue for malpractice is an essential right for all criminal defendants. While relatively few criminal defendants actually sue their attorneys for malpractice, ${ }^{149}$ the importance of this right lies not in necessarily winning damages but in deterring sub-standard representation. The implicit threat of initiating a malpractice suit deters shoddy representation because the stigma of defending oneself from malpractice is im itself a huge stam on an attorney's professional reputation..$^{150}$

To an indigent chent, however, the right to sue for malpractice is of even greater importance. Without this right, the mdigent defendant lacks any other viable means of enforcing his right to competent representation. First, an indigent client obviously cannot use financial mcentives to ensure an adequate defense; unlike a paying chent, he carmot hire and fire counsel at will. Second, given the Supreme Court's ruling that public defenders do not act "under color of state law" when performing traditional attorney functions, an indigent defendant is effectively foreclosed from bringing a federal civil rights suit under 42 U.S.C. $\S 1983$ to vindicate his right to counsel. ${ }^{151}$ Third, while the Scott case suggests that bar

149. According to one study, criminal malpractice cases comprise only $3 \%$ of all malpractice claims. The areas of law that have the highest incidence of malpractice are plaintiff's-side personal injury/property damage cases (25\%) and real estate cases (23\%). AMERICAN BAR ASSOCIATION, PROFILE OF LEgAL MALPRACTICE: A STATISTICAL STUDY OF DETERMINATIVE CHARACTERISTICS OF ClAIMS ASSERTED AGAINST ATTORNEYS 8 (1986) [hereinafter A.B.A. PROFILE].

150. See, e.g., Tom W. Bell, Comment, Limits on the Privity and Assignment of Legal Malpractice Claims, 59 U. CHI. L. REV. 1533, 1534 (1992) (commenting that "the threat of being sued for legal malpractice haunts the thoughts of practicing attorneys").

151. See supra note 71-72 and accompanying text; see also David A. Sadoff, Note, The Public Defender as Private Offender: A Retreat from Evolving Malpractice Liability Standards for Public Defenders, 32 AM. CRIM. L. REv. 883, 895-96 (1995). 
associations and courts can discipline attorneys for incompetent representation, ${ }^{152}$ an imdigent defendant realistically cannot pursue this remedy if he is imcarcerated. While it is conceivable that bar associations and courts in immumity jurisdictions would implement these professional standards, it is more likely that these bodies would be sympathetic of the imdigent-defense attorneys' burdens and thus be hesitant to discipline them for errors that are not legally actionable. Finally, the only other remedy available to mdigent defendants, a post-conviction action for ineffective assistance of counsel as set forth in Strickland v. Washington, ${ }^{153}$ neither provides for damages nor sanctions the attorney for madequate representation. Although these suits free an indigent defendant froin an improper conviction, they do nothing to vindicate the right to counsel. More importantly, criminal defense attorneys have hittle fear of meffective-assistance-of-counsel suits because the Strickland standard is extremely narrow and all but impossible to satisfy. ${ }^{154}$ As a result, ineffective-assistance-of-counsel suits have httle deterrent value. Thus, in hight of the absence of other viable remedies, foreclosing the right to sue for malpractice precludes an mdigent from enforcing his right to adequate representation.

Exaggerating the threat of frivolous malpractice suits, the Browne and Dziubak courts expressed fears that the no-immunity rule would encourage dissatisfied chents to sue their appointed counsel for nualpractice, ultimately diverting scarce resources from public defense and discouraging lawyers frons serving as indigent-

152. See Scott v. Niagara Falls, 407 N.Y.S.2d 103, 105 (N.Y. Sup. Ct. 1978).

153. Under the ineffective-assistance-of-counsel remedy outlined in Strickland v. Washington, 466 U.S. 668 (1984), an aggrieved defendant must prove that his attorney's representations fell below an objective standard of reasonableness and that the outcome of his case would have been different but for his attorney's errors. Id. at 688 (finding that "the defendant inust show that the counsel's representation fell below an objective standard of reasonableness" and that "the performance mquiry must be whether counsel's assistance was reasonable considering all the circumstances"); Id. at 694 (finding that "the defendant must show that there is a reasonable probability that, but for counsel's unprofessional error, the result of the proceeding would have been different").

154. See, e.g., Marianne Lavelle \& Marcia Coyle, Effective Assistance: Just a Nominal Right?, NAT'L L.J., June 11, 1990, at 42 (quoting Stepheu B. Bright, director of the Southern Prisoners Defense Committee in Atlanta, as saying that "[the ineffective-assistanceof-counsel] standard has coine down, down, down"). This article also provides a chart showing how many ineffective-assistance-of-counsel suits were successful in certain federal appellate courts since 1984. In the Fifth Circuit, for example, relief was granted in only one of 32 ineffective-assistance-of-counsel cases. Id. 
defense attorneys. ${ }^{155}$ These courts, however, ignore the fact that the inherent difficulty of bringing a successful criminal malpractice action as an mdigent helps ensure that only meritorious cases will ever be litigated. Several obstacles prevent indigent defendants from suing their attorneys for baseless claims. To bring a successful legal malpractice action, a plaintiff generally must show four elements by a preponderance of the evidence: ${ }^{156}$ (1) a legal duty between the attorney and client; (2) an act or omission constituting a breach of that duty; and (3) an mjury to the client measurable in damages that is (4) proximately caused by the attorney's breach. ${ }^{157}$ An indigent malpractice plaintiff will undoubtedly have great difficulty satisfying this negligence standard. The indigent plaintiff, who is probably incarcerated, must first convimce a lawyer to take his case on a contingency basis. $\mathrm{He}$ also has to retain another lawyer to serve as an expert witness to testify that his defense attorney breached the applicable standard of care. In both cases, attorneys are unlikely to take part in such a case unless it is truly meritorious; lawyers generally avoid suing other lawyers, let alone on behalf of an indigent defendant. ${ }^{158}$ Furthermore, the overwhelming majority of legal malpractice cases provide minimal financial incentive. ${ }^{159}$ In light of these considerations, it is no surprise that none of the immuntity courts used empirical data to substantiate their fear of malpractice suits brought by indigent defendants.

C. Malpractice Immunity Has Substantial Costs for the Legal Profession and Society as a Whole

The immunity courts also fail to realize that malpractice im-

155. See supra notes $93,123-25$ and accompanying text.

156. W. PaGe Keeton et aL., Prosser and Keeton on the LAW of Torts $\S 38$, at 239 (5th ed. 1984).

157. Id. § 30 , at $164-65$.

158. A self-help guide to suing for legal malpractice recognized this fact: "Members of the legal profession traditionally have been unwilling to sue their fellow lawyers, and those willing to do so are picky about the cases they take because malpractice cases are hard to win." DIRECTORY OF LAWYERS WHO SUE LAWYERS 1 (1989). Of course, a criminal defendant can try to proceed pro se against his former counsel. However, given the relative complexity of litigating a malpractice case that probably requires expert testimony, a pro se claim is unlikely to succeed.

159. According to oue study, $70 \%$ of all closed legal malpractice clains paid less than $\$ 1,000$ to the claimant. Only $8 \%$ of all claims paid more than $\$ 25,000$. A.B.A. PROFILE, supra note 149 , at 65 . 
Inunity imposes tremendous costs not only on indigent defendants but also on the legal profession and society as a whole. The immunity courts would like to believe that freeing public defenders and court-appointed counsel from civil hability yields only positive results for all parties concerned, especially the conservation of limited resources in order "to provide an effective defense to the greatest number of indigent defendants."160 This view, however, is a mirage. When courts grant malpractice immumity, indigent defendants are only one of the parties who suffer. Incoinpetent representation does not result in increased savings for the courts and taxpayers. On the contrary, mept lawyering that cuts corners in the slort run inevitably leaves nore issues to be raised in habeas corpus and post-conviction proceedings. Indigent clients, although lacking money, are not without their wits and common sense. If a criminal defendant meets with his attorney only twice before trial, if necessary witnesses are not called, or if basic elements of the defense are not presented, he is aware that mistakes have been made. Every time a dissatisfied imdigent defendant files a habeas corpus petition or an ineffective-assistance-of-counsel suit, taxpayers nltimately bear the financial burden of relitigating these issues. ${ }^{161}$ The irony is that if coinpetent representation had been available from the outset, these issues would have been raised and resolved at the trial level. ${ }^{162}$

Malpractice immunity carries another cost tliat far outweighs its financial expense: its effect on how the public perceives the legal profession and how the profession views itself. The very idea of shielding attorneys from malpractice communicates that in this situation, lawyers liave been absolved of their ethical responsibilities. Cases such as Scott, Coyazo, and Dziubak contend that iminumity enables the indigent-defense attorney to conserve lier time, energy, and limited funds in order to best serve the indigent popu-

160. Dziubak v. Mott, 503 N.W.2d 771, 777-78 (1993); see also supra notes 122-25 and accompanying text.

161. See, e.g., Robert J. Glennon, The Jurisdictional Legacy of the Civil Rights Movement, 61 TENN. L. REV. 869, 915 (1994) (recognizing that "[h]abeas corpus post-conviction proceedings place heavy costs on federal judicial resources").

162. As a practical matter, both state and federal courts bear the costs of post-conviction proceedings. At first glance, the states may appear to enjoy some savings because the federal courts assume a portion of these costs, particularly for habeas corpus cases. One should remember, however, that individual taxpayers-the citizens of the states-ultimately pay for the administration of the federal courts. 
lation. ${ }^{163}$ This absolution of professional responsibihity, however, would be shocking in any other setting. For instance, no court would protect a state-paid doctor from liability for negligent medical care on the grounds that he is underfunded or too busy. Society would never accept this no-liability stance, even if the doctor is treating the poor. ${ }^{164}$ These "situation ethics" confirm the worst pubhic cynicism about lawyers and the legal profession. ${ }^{165}$ Moreover, it is important to recognize who is granting immumity to lawyers in this case. When the public realizes that the courts-the institutions entrusted to uphold the canons of legal ethics, the professional responsibility of the bar, and the idea of equahty before the law-are using their power to exempt attorneys from their ethical responsibilities, the legal profession will inevitably lose its credibility in the eyes of the public. Thus, contrary to the view of the immunity courts, there are tremendous monetary and psychic costs associated with the grant of malpractice immunity.

\section{Exposing Malpractice Immunity as an Attempt to Protect the Public Treasury at the Indigent Defendant's Expense}

The recent embrace of malpractice immunity for indigentdefense counsel combined with its overall weakness as a legal doctrime suggest that another reason is driving its increased prominence. This reason, it appears, is the desire to protect the state treasury from having to pay damages to indigent defendants for malpractice suits. The time never has been more ripe for a disgruntled indigent client to bring a successful nalpractice suit against his public defender or court-appointed attorney. The "war on drngs" and the concomitant mcrease in crime have precipitated a crisis in indigent defense that has strained the states' ability to

163. See supra notes $77-78,109,122-123$ and accompanying text.

164. See, e.g., Becker v. Janinski, 15 N.Y.S. 675, 677 (N.Y. Com. Pl. 1891) ("Whether the patient be a pauper or a millionaire, whether he be treated gratuitously or for reward, the physician owes him precisely the same measure of duty, and the same degree of skill and care."); John A. Siliciano, Wealth, Equity, and the Unitary Medical Malpractice Standard, 77 VA. L. REv. 439, 441 (1991) ("To date, medical malpractice law has refused to recognize formally the economic status of the patient as a factor legitimately influencing the kind or degree of care the patient receives.").

165. The public already holds the legal profession in disrepute. See, e.g., Colin Covert, Lawyers Losing Case with Public, STAR TRIB., May 29, 1994, at 1E (observing that "lawyers are relatively popular with people who don't know one" and that "[p]ublic cynicism about the [legal] profession is rampant-and getting worse"). 
provide adequate counsel to all indigent defendants. ${ }^{166}$ Moreover, the taxpaying public lias becoine increasingly unwilling to provide adequate funds to sustain indigent-defense programs. ${ }^{167}$ At a time when many indigent-defense attorneys are handling hundreds of cases annually, the inadequate representation of indigent defendants is in danger of becoming the general rule rather than the exception. Well aware of this harsh reality and expecting no relief from the legislature, the immunity courts have fashioned their own response to the indigent-defense crisis. In essence, they have used malpractice immunity as a sub rosa means of protecting the state treasury from the very real risk that indigent defendants will successfully sue their public defenders and court-appointed counsel for malpractice. ${ }^{168}$

In evaluating this change in the law, a tragic irony soon becomes apparent: The state courts that have granted immunity have turned their backs on the Supreme Court's progressive Sixth Amendinent jurisprudence. In inaking the right to counsel a constitutional right, the Gideon Court recognized that our adversary systein is incapable of dispensing justice when an accused individual lacks competent legal representation. In this liuniane spirit, Gideon and its progeny were intended to protect the rights of the indigent criminal defendant-the weakest member in our criminal justice system-froin the powerful hands of the state. Yet, by transferring the burdens of the criminal justice system onto their weary slioulders, malpractice immumity effectively reverses these roles. The doctrine of inalpractice immunity now serves as a buffer to protect the state and its treasury froin the imdigent defendant. Sadly, the courts granting immunity have lent their imprimatur to a judicial device that emphasizes fiscal expediency and convemience over the protection of a constitutional right. ${ }^{169}$

166. See supra notes 33-40 and accompanying text.

167. See supra notes $41-45$ and accompanying text.

168. The immunity courts would probably deny that the fear of paying damages for malpractice is animating the decision to grant immunity. Only one court, the Coyazo court, has countenanced that "protect[ing] the public treasury" is a legitimate reason for extending malpractice immunity. Coyazo v. State, 897 P.2d 234, 240 (N.M. Ct. App. 1995).

169. If a state legislature passes a law granting immunity to indigent-defense attorneys, one may argue correctly that the courts are obligated to follow this statute. The courts discussed in this Note, however, have not deferred to the legislature's judgment; rather, they have seized the mitiative and chosen to grant immunity on their own accord. 


\section{RECOMMENDATIONS}

The inherent unfairness of this change in the law prompts the question of what, if anything, can be done to address the problems associated with the doctrine of inalpractice immunity. Several comnientators have undertaken this task and have offered proposals for reform. ${ }^{170}$ All voicing reservations about the use of malpractice immunity as a legal doctrine, these commentators contend that the mdigent defendant should retain in some form the right to sue for nralpractice. However, in recognition of the nature of the indigent-defense attorney's job and the harsh economic realities that beset most indigent-defense programs, these commentators propose that this right be modified. One commentator advocates a "twopronged solution" that would require courts to modify the evidentiary threshold for proving ineffective assistance of counsel while simultaneously extending limited statutory hability to public defenders as state employees. ${ }^{171}$ Another has designed a model statute that requires the indigent client to prove his malpractice action by a standard of clear and convincing evidence. ${ }^{172}$ Yet another commentator has proposed a "sensible malpractice liability standard" that would use an ordinary tort negligence standard but would immunize public defenders from liability when "budgetary constraints" prevent them from hiring necessary out-of-office experts, specialists, or translators. ${ }^{173}$

Although admirable in their attempt to address a seemingly intractable problein, these proposals miss the point. While all of these commentators recognize the nranifest unfairness of denying mdigent individuals the "ability to hold their criminal defense lawyers nronetarily accountable for unsatisfactory representation,"174 their proposals ultimately leave indigent defendants with an emasculated, meffective right to sue for nualpractice. The "twopronged solution," which recommends that public defenders re-

170. See infra notes 171-73 and accompanying text.

171. See Rutherford, supra note 114, at 1005-10.

172. See Richards, supra note 114 , at $550-56$.

173. See Sadoff, supra note 151, at $921,930-31$.

174. Rutherford, supra note 114, at 1002; see also Richards, supra note 114 , at 550 ("Rather, under a rule of public defender malpractice immunity, some people would be allowed to sue negligent attorneys while others would not."); Sadoff, supra note 151, at 903 ("If indigent criminal defendants were foreclosed from suing their attorneys while economically advantaged defendants could continue to bring malpractice claims agaimst private counsel, the system would strike us as unfair."). 
ceive "limited statutory liability" as state employees, is merely a form of qualified immunity. This proposal ignores the fact that a public defender simply cannot serve two clients-the defendant and the state-at the same time. ${ }^{175} \mathrm{Next}$, the model statute requiring an indigent client to prove his malpractice suit by clear and convincing evidence violates the basic assumption that an indigent client should lave the same rights and privileges as a paying client. ${ }^{176}$ This proposal fails to appreciate the umique importance that the right to sue for malpractice luas to the imdigent defendant. ${ }^{177}$ Finally, the "sensible malpractice liability standard" that immunizes a public defender froin liability when budgetary constraints prevent him from hiring a required outside expert, specialist, or translator gives legal sanction to the idea that the poor are not entitled to an effective, thorough defense. Under this proposed standard, an insane defendant who lacks money would have no redress against a public defender who did not hire a psychiatric expert for his defense. Similarly, an indigent defendant who only speaks Spamish would have no rehef agamst an appoimted attorney who did not retain a translator. Not fully appreciating that the right to sue for malpractice is an essential right that all criminal defendants must possess in its pure, unadulterated form, these commentators erroneously accept the premise that malpractice immumity can be used as a legitimate means for coping with the indigent-defense crisis.

These recommendations ultimately fail because they do not squarely address the root of the indigent-defense crisis: the madequate funding of legal representation programs for indigent clients. Although legal theories that support the use of intrusive judicial remedies to attack the problem of underfunding exist, none of these theories are particularly promising in the context of the right to counsel. For instance, one could argue that the grant of malpractice immunity violates the indigent defendant's constitutional right to equal protection vis-à-vis the Sixth Amendment ${ }^{178}$ and therefore necessitates an intrusive court-ordered remedy. ${ }^{179}$ How-

175. See supra notes $139-44$ and accompanying text for further discussion of this contradiction.

176. As with most tort cases, the evidentiary standard for malpractice cases is by preponderance of the evidence. See supra note 156 and accompanying text.

177. See supra notes $149-54$ and accompanying text.

178. Two of the aforementioned commentators have also suggested this argument. See Pedersen, supra note 114, at 1044-45; Richards, supra note 114 , at 547-50.

179. See, e.g., Missouri v. Jenkins, 495 U.S. 33 (1990) (considering a judicially imposed 
ever, Supreme Court precedent does not consider wealth to be a sufficient basis for identifying a suspect class $^{180}$ nor does the Equal Protection Clause require "absolute equality or precisely equal advantages." 181 Unsurprisingly, the sole immunity court to consider such au equal protection challenge, the New Mexico Court of Appeals, rejected it. ${ }^{182}$ One could also argue that the judiciary should exercise its "inherent power" to compel adequate funding for indigent-defense programs. The imherent power doctrine emphasizes that "the judicial system, as one of the branches of government, must claim and exert certain powers to maintain the integrity of the judicial branch." ${ }^{\prime 183}$ Unfortunately, the inherent power doctrine generally is invoked to vimdicate structural, separation-of-powers interests rather than individual rights such as the right to counsel. ${ }^{184}$ Furthermore, state courts have been more hesitant than federal courts to adopt intrusive remedies. ${ }^{185}$

tax to fund a school desegregation remedy).

180. See San Antomio Sch. Dist. v. Rodriguez, 411 U.S. 1, $24-29$ (1973). See also Frank I. Michelman, Foreword: On Protecting the Poor Through the Fourteenth Amendment, 83 HARV. L. REV. 7, 27 (1969) (stating that considering wealth as a suspect classification is "endemically troublesome as a matter of principle").

181. Rodriguez, 411 U.S. at 24. Moreover, in Ross v. Moffitt, the Court held that a state's refusal to appoint counsel in the later stages of the appellate process did not violate the Equal Protection Clause. 417 U.S. 600,610 (1974). The court set forth the following standard for deciding equal protection challenges involving indigent defendants in this situation:

The duty of the State . . i is not to duplicate the legal arsenal that may be privately retained by a criminal defendant in a continuing effort to reverse his conviction, but only to assure the indigent defendant an adequate opportunity to present his claims fairly in the context of the State appellate process.

Id. at 616.

182. Coyazo v. State, 897 P.2d 234, 241 (1995).

183. Gabrielle T. Letteau, Note, Crisis in California: Constitutional Challenges to Inadequate Trial Court Funding, 22 HASTINGS CONST. L.Q. 557, 575 (1995); see also Howard B. Glaser, Wachtler v. Cuomo: The Limits of Inherent Power, 14 PACE L. REV. 111 (1994); André Doguet, Note, McCain v. Grant Parish Police Jury: Judicial Use of the Inherent Powers Doctrine to Compel Adequate Judicial Funding, 46 LA. L. REV. 157 (1985).

184. See Letteau, supra note 183 , at $575-82$. The inherent power doctrine also varies with the constitutions of individual states. Id.

185. See, e.g., Note, Unfulfilled Promises: School Finance Remedies and State Courts, 104 HARV. L. REV. 1072, 1073-85 (1991) (discnssing the judicial reluctance to use intrusive remedies as manifested in the extensive state constitutional litigation over school finance equity). Applying inherent power doctrine to the right-to-counsel context inay also undermine the basic assumption that indigent-defense attorneys operate independently of the judiciary. 
Ironically, the no-immunity rule itself provides a structural check to the problem of madequate funding of indigent-defense programs. ${ }^{186}$ It is axionuatic that large tort judgments tend to compel proper behavior. ${ }^{187}$ Allowing indigent defendants to bring nualpractice suits serves as a way of holding the legislature accountable for its decision to withhold adequate funding for these programs. While few legislatures would increase funding for indigent defense voluntarily, ${ }^{188}$ they may do so if indigent clients are able to bring successful inalpractice suits against their attorneys with regularity. Moreover, the very idea of liaving the state pay dainages to indigent defendants is a humiliating scenario that most legislatures would want to avoid. For these reasons, having the state pay tort damages to indigent clients accomplishes soinething that the doctrine of immunity could never do: prod the legislature to deal forthrightly with the indigent-defense crisis by appropriating sufficient funds to deal with the increased numbers of indigent defendants in the criminal justice systent. ${ }^{189}$

\section{CONCLUSION}

The writer James Baldwin once observed that "[a]nyone who has ever struggled with poverty knows how extremely expensive it is to be poor." 190 The experience of the nation's indigent criminal defendants, who are already the weakest parties in our criminal justice system, attests to the accuracy of this statement. Having grown even poorer as malpractice immunity has gained adherents,

186. Of course, the ideal solution is for the legislature to appropriate sufficient funds for indigent-defense services on its own volition. But given the unpopularity of poor criminal defendants and the reasons discnssed supra Section I(B), it is extrennely unlikely that any legislature would even consider such legislation. See Mounts, supra note 22, at 482 (observing that politicians "at best, ha[ve] little to gain by advocating large expenditure for the defender office, and at worst, much to lose").

187. See, e.g., Macmillan v. Redman Homes, Inc., 818 S.W.2d 87, 95-96 (Tex. Ct. App. 1991) (finding that "one of tort law's goals-and one of its results-is to deter conduct and shape behavior").

188. See supra text accompanying note 186 .

189. One may argue that laving to pay a large anount of damages to an indigent defendant simply would galvanize the legislature to pass a statute granting malpractice immunity. While this argument is not without basis, the courts should refrain from taking the initiative in using malpractice doctrine in this manner. See supra text accompanying note 169 and notes $160-65$ and accompanying text.

190. James Baldwin, Fifth Avenue, Uptown, in NoBody KNows MY NAME 56, 62 (1961). 
these citizens have been forced to surrender a truly priceless right-the constitutional guarantee of the right to counsel.

The poverty of these criminal defendants, however, pales in comparison to the intellectual and ethical impoverishment of malpractice immunity itself. By merely transferring the burdens of the indigent-defense crisis, the immunity courts have sanctioned a legal doctrine that is inconsistent with the core principles that undergird our adversary system of criminal justice. Tragically, these courts have disregarded the rights of the indigent defendant and have failed to account for the tremendous fimancial and psychic costs that malpractice immunity inevitably brings. In this myopic effort to save taxpayer dollars, these courts have effectively extinguished Gideon's guarantee that the accused shall have the right to conipetent representation in all criminal trials. 